\title{
Building bridges between different levels of education: Methodological proposals for CLIL at university
}

\author{
Jesús Ángel González \\ jesusangel.gonzalez@unican.es \\ Javier Barbero \\ javier.barbero@unican.es \\ Universidad de Cantabria, Spain
}

\begin{abstract}
This article describes a research project carried out at the University of Cantabria, Spain. Having identified a lack of communication between different levels of the education system, the co-authors have carried out qualitative research ("long interviews" with Primary and Secondary CLIL teachers) in order to identify the best methodological guidelines to be followed in CLIL classes. These guidelines have been summarized in a CLIL-methodology Decalogue to be used at the Tertiary Level.
\end{abstract}

Keywords: CLIL, university, methodology, guidelines, scaffolding, student-centred

\section{INTRODUCTION}

Although much has been written about the benefits of CLIL in Primary and Secondary Education (for example, Muñoz 2007, Dalton-Puffer 2007, Lasagabaster and Sierra 2009, Liubinienè 2009 or Vártuki 2010), there are not so many documented experiences of CLIL at the Tertiary Level (with the notable exceptions of Wilkinson 2004, Wilkinson and Zegers 2007, 2008, Fernández 2009, or Costa and Coleman 2010). Paradoxically, due to "the growth of student mobility and the evolving epistemology of university disciplines in a globalising academy” (Costa and Coleman 2010), more and more universities across Europe are teaching courses and even whole degrees in a second language, almost always English. However, university lecturers do not seem to take advantage of CLIL research and experiences from other levels of education, probably because, as Costa and Coleman state, ICLHE (Integrating Content and Language in Higher Education, as CLIL at university is often referred to) "typically represents a top-down approach, an institutional initiative dictated by the strategic need for internationalization” (2010: 20), and one that does not take into account CLIL at other levels. This article describes an action-research project intended to create a bridge 
between different levels of education, in order to try to incorporate the best methodological practices from other educational contexts into University, and use CLIL as a "catalyst for change” (Marsh and Frigols 2007) towards a student-centred teaching methodology.

\section{BACKGROUND}

Like many other areas in Europe, Cantabria, a small region on the Northern Spanish coast, has embraced CLIL enthusiastically in compulsory levels of education. The first bilingual programme was put into practice thanks to an official agreement between the Regional Education Authority, the National Education Authority and the British Council back in 1996. In the following years, dozens of bilingual programmes were implemented by the Regional Education Authority with the participation of a remarkable number of teachers. Currently, we have 54 bilingual schools with a total of 57 bilingual programmes in English, French and German.

The University of Cantabria is a young, dynamic public institution with an increasing European and international dimension. In order to enhance its level of internationalization, in 2008 it decided to demand of its new graduates an advanced command of English (B2 level according to the Common European Framework for Languages) by the end of their studies. In order to demonstrate this level of English, students may either submit an official certificate issued by an external institution or pass a proficiency exam organized by the University. Following the European Union's recommendations about plurilingualism, the University also decided that students could fulfil this language requirement by demonstrating a B1 level in English and a B1 command in another European language. Students can also fulfil the University's language requirement with a B1 in English if they complete 30 credits in an exchange programme carried out in a foreign language or if they obtain one of the Diplomas in English offered by the University.

In order to enable students to reach those levels and to guarantee their acquisition, the Language Policy Division of the University (Área de Capacitación Lingüística) designed a Language Policy Plan (Plan de Capacitación Lingüística) which included measures such as the following: 
- Organization of proficiency exams to certify the language levels described above. The exams follow the general recommendations of the European Association of Language Testers (EALTA) and test the students' competence in the following skills: reading comprehension, listening comprehension, writing, and speaking production and interaction. Students need to achieve a pass mark in all the different sections of the exams, which are held twice a year. The exams are designed and organized by the Vicerectorate for Internationalization and the testers are English language teachers from the University’s Language Centre and the Department of Philology, who follow the Council of Europe's guidelines and use samples provided in projects like CEFTRAIN (Common European Framework of Reference for Languages in Teacher Training) and the DVD "Spoken performances illustrating the 6 levels of the Common European Framework of Reference for Languages” (2013).

- Introduction of an English compulsory core subject during the first or second year of all the BA/BSc degrees.

- Introduction of English as a second language of instruction throughout all the degrees, making sure that all the undergraduate degrees offer as many subjects taught in English as possible. Students had to follow at least a 6-ECTS course taught in English in order to achieve the language requirement.

Although a B2 in English at the end of undergraduate studies might be considered a rather conservative requirement, it is certainly a very demanding goal within the context of Spanish Higher Education. The level of English obtained by most students at the end of their secondary education is unfortunately very far from what should be expected. According to the First European Survey on Language Competences of the European Commission, carried out in 2011 (Surveylang 2012), the levels of Spanish students in their last year of compulsory education (16-year-old students) are as follows:

Table 1. Percentage of pupils at each level (global average of the 3 skills).

\begin{tabular}{|l|l|l|l|l|}
\hline Pre A1 & A1 & A2 & B1 & B2 \\
\hline 22 & 35 & 16 & 14 & 13 \\
\hline
\end{tabular}

As we can see, only around one quarter of the students are able to show an independent level (B1 or B2) in English by the end of their compulsory education. We also need to 
remember that this survey only tested Reading Comprehension, Listening Comprehension and Writing; it did not test the students' competence in Spoken Production and Interaction, presumably the least practised of the skills. If we compare this with the European average by skills (Table 2), we can see how Spanish students perform between 12 (Reading Comprehension) and 21 (Listening Comprehension) points lower than the European average:

Table 2. Percentage of pupils at broad levels by skill.

\begin{tabular}{|c|c|c|c|c|c|c|c|c|c|}
\hline & \multicolumn{3}{|c|}{ Reading } & \multicolumn{3}{|c|}{ Listening } & \multicolumn{3}{|c|}{ Writing } \\
\hline & Pre A1 & $\mathrm{A}$ & $\mathrm{B}$ & Pre A1 & $\mathrm{A}$ & B & Pre A1 & $\mathrm{A}$ & $\mathrm{B}$ \\
\hline Spain & 18 & 53 & 29 & 32 & 44 & 24 & 15 & 58 & 27 \\
\hline $\begin{array}{l}\text { European } \\
\text { Average* }\end{array}$ & 14 & 45 & 41 & 17 & 38 & 45 & 11 & 49 & 40 \\
\hline
\end{tabular}

These results are particularly shocking if we take into account the number of hours of instruction that Spanish students receive in their 10 years of compulsory education (960 hours, according to Gozalo 2011: 2).

One could think that in the next two non-compulsory years of Bachillerato, the results would improve, particularly if we consider the generally very positive results of the Access to University Exams in Spain: as an example, 80.5\% of the students passed the English Language section of the exam organized by the University of Cantabria in June 2012. This exam does not use the Common European Framework as a reference, but the specifications seem to be referring to a level easily identifiable as B1. For example, the two main objectives of the two-year Bachillerato are to "use oral English with enough fluency and clarity to get by in daily situations", and to "use written English with coherence, clarity, and lexical and grammatical accuracy to produce simple texts of different types”. However, the exam only tests Reading Comprehension, based on a 250-word text, and Writing, based on a 120-150-word text.

Despite the $80.5 \%$ of pass marks in the exam, the real level of English that students bring to the university's classrooms is far from this picture of success: based on the B1/B2 certificates provided by the students, as well as their performance both in our proficiency exams (all skills considered) and in the placement tests (multiple-choice exam testing grammar, vocabulary, reading and listening comprehension) administered 
in their compulsory English subject, more than half of the students (54\%) have not reached the independent level:

Table 3. Percentage of students achieving CEF levels. 2012-2013 University of Cantabria's first-year students (except 5 degrees, $2^{\text {nd }}$ year). Percentage based on certificates provided by students and their performance in the University's proficiency exams and placement tests.

\begin{tabular}{|c|c|c|c|c|c|}
\hline A1 & A2 & B1 & B2 & C1 & C2 \\
\hline 7.08 & 47.16 & 22.95 & 21.56 & 1.12 & 0.13 \\
\hline
\end{tabular}

It is obvious that this level of English (and we fear that if the placement test had included a Speaking section the percentage of students with a B level would have decreased) is an important challenge not only for students who need to reach a B2 level by the end of their four-year studies, but also for university lecturers willing to teach their subjects in English.

Once the evidence of the students' level of English became available, the Language Policy Division of the Vicerectorate of Internationalization decided to take a number of measures to make it easier for students with a lower level to fulfil the linguistic requirement. On the one hand, the University decided to accept temporarily (at least until the Access to University Exam includes a skills-based English exam, with an expected positive washback effect in the students' instruction) a B1 level in English as long as the students showed evidence of additional instruction in English (at least 12 credits). On the other hand, the University set up and developed an Internet English Resource Centre (http://www.unican.es/Vicerrectorados/vinternacionales/recursos.htm) where students can practise and improve their English skills on-line, and it also increased the offer of extracurricular English courses for the students.

But if the students' level of English is an important handicap, a second problem might lie on the other side of the desk: are our university lecturers qualified to teach their subjects in English? From the point of view of their linguistic proficiency, the University of Cantabria decided that the lecturers willing to teach their subjects in English needed to have a C1 level in that language. The system designed to demonstrate this level was either to provide an official certificate issued by an external institution or to take part in an internal process made up of two stages: the completion of a Linguistic Self-Report and participation in an interview with two English professors from the 
Department of Philology. The Linguistic Self-Report is based on the Europass Language Passport and includes a self-assessment of language skills, as well as a section for English language diplomas or certificates, and a list of linguistic experiences, including previous teaching experience in English and research stays. The results of this process have actually been very encouraging: at the time of writing, as many as 70 teachers have been able to provide a C1 certificate and $86 \%$ of the nearly 100 teachers who have taken part in the second system have demonstrated C1-level proficiency in English. However, in these interviews a second problem arose: most of the teachers interviewed were planning to translate into English the materials (photocopies, handouts, PowerPoint presentations) they had been using in Spanish before, without taking into account the fact that their students' level of English had, in most cases, nothing to do with their expectations. Most of them had not given too much thought to a change in methodology, let alone a CLIL-oriented one. These interviews therefore confirmed our ideas about the need to build a bridge between the different levels of education and help university lecturers to adopt a new methodological perspective, based on CLIL research and practice, when teaching their subjects in English.

\section{RESEARCH PROJECT}

In order to collaborate with the University in the implementation of this Plan, the coauthors of this paper set up a Group of Educational Innovation and Research, whose main aim was to help content teachers in their use of English as the vehicle for their teaching practice. Inspired by action-research principles, and having identified a problem in the University lecturers' perspective on the implications of teaching content through English, we decided to develop a research project to ask our colleagues at Primary and Secondary schools about the best way to proceed in order to implement CLIL at university. Following DiCicco-Bloom and Crabtree "Whatever the focus of the study, the basic research question needs to be sufficiently focused so that a relatively homogenous group will have shared experiences about the topic” (DiCicco-Bloom and Crabtree 2006: 316), we defined our basic research question in the following terms: "What are the most important elements of a CLIL-based methodology, as applied in Primary and Secondary school, and can they be extended to the Tertiary level?”. 
Before designing our research tool, we obviously needed to check the literature published on CLIL implementation and methodology, where we found several relevant contributions. Halbach (2012), for example, has taken the distinction made by Cummins (1984) between BICS (Basic Interpersonal Communication Strategies) and CALP (Cognitive Academic Language Proficiency), as well as his framework to gauge the complexity of language tasks, as a starting point to provide guidelines to adapt difficult content tasks:

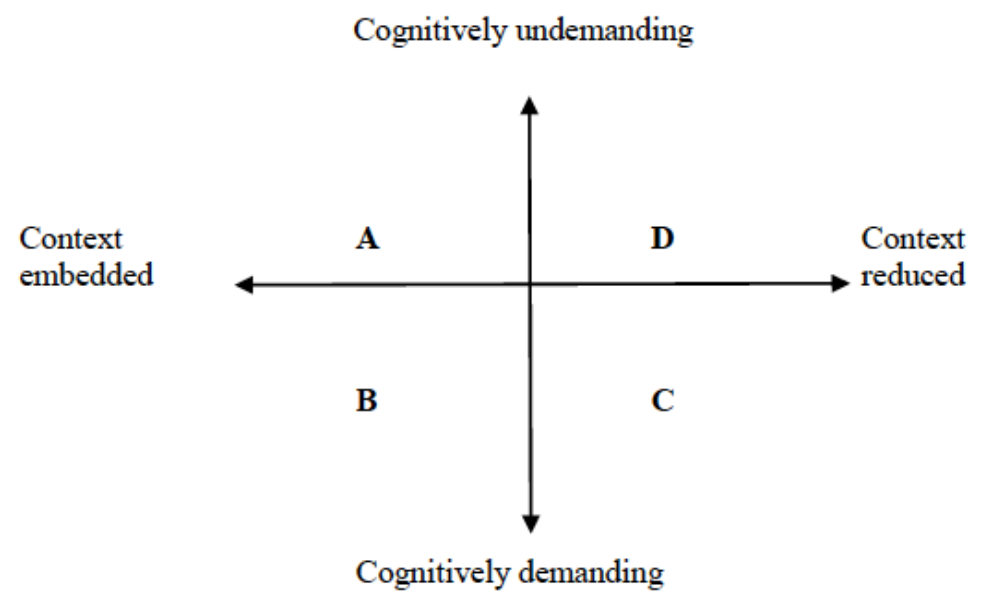

Figure 1. Cummins’ framework as adapted by Halbach (2012: 35).

Having identified the problem at Quadrant C (cognitively demanding tasks with very little context, precisely the commonest case we can anticipate at the Tertiary level), she then provides solutions by creating a context and/or scaffolding students’ performance: 


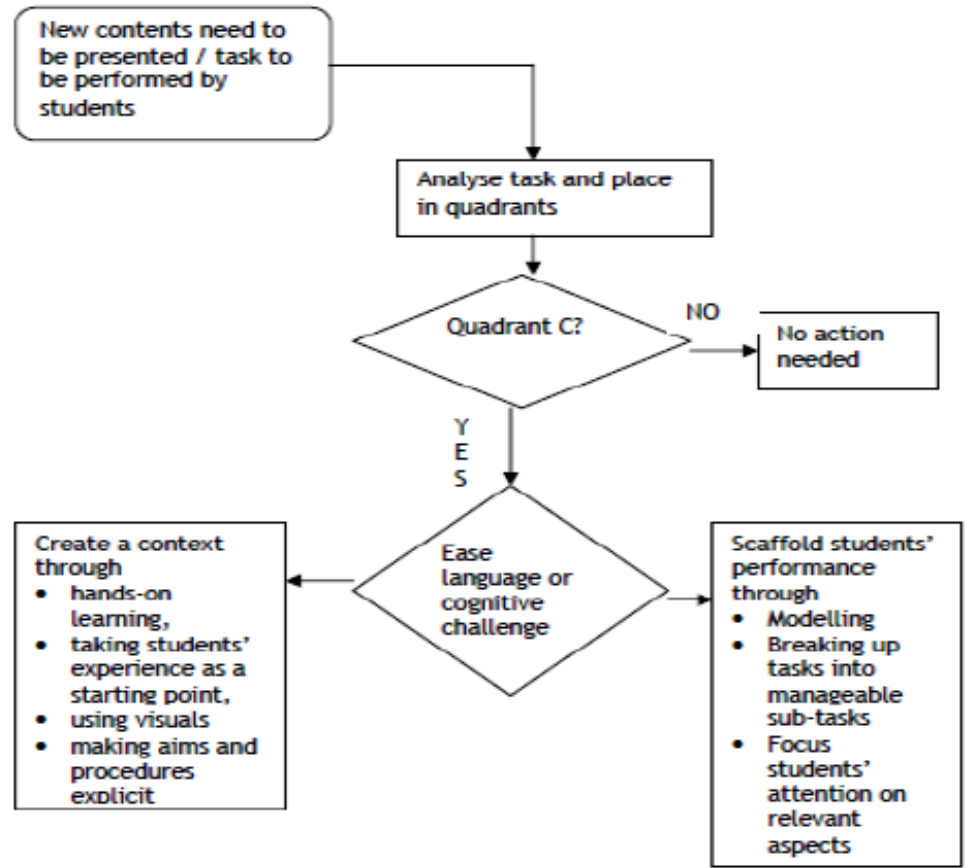

Figure 2. Adapting difficult tasks (Halbach 2012: 39).

'Scaffolding' is certainly an essential concept to apply in our University environment.

Van de Pol et al. (2010) summarize it like this:

Scaffolding is typically associated with the socio-cultural theory of Vygotsky. Wood et al. (1976) adopted the scaffolding metaphor to explain the role that adults can play in joint problem-solving activities with children. Borrowed from the field of construction (...) the use of scaffolding as a metaphor within the domain of learning refers to the temporary support provided for the completion of a task that learners otherwise might not be able to complete. This support can be provided in a variety of manners that for example include modeling and the posing of questions for different subjects (e.g., science, social studies) at different ages. (Van de Pol et al. 2010: 271-272)

According to de Graaff et al. (2007), teachers should then facilitate the following learning aspects: exposure to input at a (just) challenging level, meaning-focused processing, form-focused processing, output production, and the use of compensation strategies (de Graaff et al. 2007: 605). A very important issue here for the teachers is to identify the language demands the learner has and to provide support strategies for the learner to cope with the new situation. Of course, it is essential for he or she to have a good command of the target language and of 'classroom language' as well, so that the transition from the different parts of the lesson is smooth. The C1 requirement at our University should then probably be complemented by teacher training courses (where 
'classroom language’ may be acquired) and a system of external assessment of classes taught in English.

As for the other solution proposed by Halbach for cognitively demanding tasks (creating a context through hands-on learning, taking students' experience as a starting point, using visuals, and making aims and procedure explicit), her advice leads us to a student-centred paradigm, where teachers' new role as mediators will include new responsibilities, as summarized by Novotná et al. (2001: 126). According to them, teachers should:

- show an understanding of the amount and type of content language s/he should use during the lesson.

- contextualize new content language items and present them in a comprehensible manner combining both auditory and visual stimuli.

- break tasks down into their component parts and issue instructions for each part at a time.

- teach thinking skills and learning strategies and highlight new material using advance organizers.

- cluster content material whenever possible and frame it by relating it to past classroom or personal experience.

- show an understanding of and sensitivity to individual learners' needs.

- build their interdependence in both content and language.

- encourage cooperative learning as peer support.

The concept of progression is also very important when considering the cognitive demands of CLIL at university. The participation of students will undoubtedly have to evolve from a lower order of thinking to a higher order (Bloom 1956, Anderson and Kraftwohl 2001), which implies a constant challenge both for teachers and students. Methodology should be able to ease this evolution in an education scenario which permanently combines the learning of a foreign language and content. Different resources should then be used in the class to make sure that the evolution from one order of thinking to the other takes place (brainstorming, mind maps, note taking, observation sheets, experiments, hands-on or problem solving activities in groups, etc.):

Practitioners involved in implementing CLIL / integrated curriculum programs should be aware that learners are active constructors of their knowledge by building correlations between areas of knowledge as well as between old and new information; that cognitive conflict allows students to reach a higher level of understanding and finally, that dialogue and negotiation among students do not only promote a higher competence at a linguistic level, but also at a cognitive one. (Casal 2007: 63)

Two more issues which have been discussed in great depth in CLIL environments are assessment and the role of lexis. As far as assessment is concerned, Vázquez translates 
Nando Mäsch’s principle from German: “As much as possible in the foreign language, whatever necessary in the L1” (Vázquez 2007: 99). This idea is complemented by Domínguez (2013), also referring to Mäsch, when she states that, as far as assessment is concerned, content should be a priority over language: linguistic competence in the foreign language is an added value which should be rewarded in the assessment process, but lack of fluency should not be penalized. Additional evidence for the potential benefits that a moderate use of the L1 has for learners' language development can be found in Alegría de la Colina and García Mayo (2009), Antón and DiCamilla (1998), Storch and Wigglesworth (2003), and Storch and Aldosari (2010).

Research has also shown how important considering lexis in CLIL classes is, with proposals like Eldridge et al.'s LexiCLIL: “Key to success in a CLIL environment is the acquisition of a productive vocabulary that includes knowledge of the most frequent vocabulary items in the target language; key vocabulary in individual subject areas and key vocabulary needed to function in the educational environment” (Eldridge et al. 2010: 89). A coherent approach to vocabulary acquisition and assessment, such as the one proposed by the LexiCLIL's authors is therefore essential.

In order to find out Primary and Secondary School teachers' perceptions about the implementation of the CLIL methodology in their schools, we have used qualitative research based on individual in-depth interviews, designed to "co-create meaning with interviewees by reconstructing perceptions of events and experiences [and] to discover shared understandings of a particular group (Di Cicco-Bloom and Crabtree 2006: 316), or, as Grant McCracken defines it, "the long interview":

The long interview is one of the most powerful methods in the qualitative armory. For certain descriptive and analytic purposes, no instrument of inquiry is more revealing. The method can take us into the mental world of the individual, to glimpse the categories and logic by which he or she sees the world. It can also take us into the lifeworld of the individual, to see the content and pattern of daily experience. The long interview gives us the opportunity to step into the mind of another person, to see and experience the world as they do themselves. (McCracken 1988: 9)

Comparisons of strengths and weaknesses of the long interview with four other primary research methods are summarized in the following chart (Woodside and Wilson 1995: 39). The feature profiles of the five research methods were developed from several sources on research designs (Churchill 1991, Dillman 1978, Miller 1991): 


\begin{tabular}{|c|c|c|c|c|c|c|}
\hline \multicolumn{2}{|c|}{ Feature } & \multirow{2}{*}{$\begin{array}{l}\text { Mail Survey } \\
\text { Low- moderate }\end{array}$} & \multirow{2}{*}{$\begin{array}{l}\text { Telephone } \\
\text { interview } \\
\text { Low-moderate }\end{array}$} & \multirow{2}{*}{ 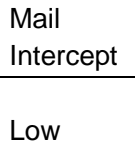 } & \multirow{2}{*}{$\begin{array}{l}\text { Long } \\
\text { interview } \\
\text { High }\end{array}$} & \multirow{2}{*}{$\begin{array}{l}\text { Participant } \\
\text { Observation } \\
\text { Very high }\end{array}$} \\
\hline 1. & Ability to verify responses & & & & & \\
\hline 2. & Response rate & Low & Moderate & High & Very high & Very high \\
\hline 3. & $\begin{array}{l}\text { Ability to probe, learn } \\
\text { reason why responses }\end{array}$ & Low & Moderate & Moderate & High & Very high \\
\hline 4. & $\begin{array}{l}\text { Cost per completed } \\
\text { interview }\end{array}$ & Lowest & Low & Moderate & High & Very high \\
\hline 5. & $\begin{array}{l}\text { Ability to describe } \\
\text { purchase and use (what, } \\
\text { when, who, how. where) }\end{array}$ & High & Moderate & Moderate & High & Very high \\
\hline 8. & Capability for autodriving & Lowest & Low & Moderate & High & Very high \\
\hline 9. & $\begin{array}{l}\text { Ability to generalize } \\
\text { results to a population }\end{array}$ & High & High & Low & Very low & Very low \\
\hline 10. & $\begin{array}{l}\text { Ability to generalize } \\
\text { results to theories-in-use }\end{array}$ & Moderate & Low & Low & High & High \\
\hline
\end{tabular}

Figure 3. Feature comparisons of Primary Data Collection Methods (Woodside and Wilson 1995: 39).

The features of in-depth interviews are defined by Woodside and Wilson (1995: 39) in the following way:

a) a face to face meeting with the interviewer and respondent; b) interviewing the respondent in his or her life space, that is, the environment related to the topic under study; c) asking open-ended, semi-structured questions with deeper exploration of unexpected topics related to the study as opportunities occur; d) tape recording of responses (when not disruptive) during the interview; e) verification of responses by triangulation of research methods (eg., comparing answers with data from direct observation and documents); and f) developing thick descriptions of individual cases.

In accordance with this model, we selected a number of participants within our region who work as CLIL teachers in schools with official Bilingual Programmes approved by the Regional Education Authority. The teachers interviewed belong to both the Primary and Secondary sphere, so that we could observe a whole picture of the compulsory education system in Cantabria. Furthermore, we chose both public schools (two of these working under the umbrella of the triple agreement between the regional Education Authority, the National one and the British Council) and state-subsidized schools ("centros concertados"). As to the teachers themselves, we wanted to have both native and non-native English speakers, men and women, and CLIL teachers (covering as much as seven different subjects of the Spanish curriculum taught in English) as well as English language teachers (who also collaborate in the CLIL programmes). Participants’ CLIL teaching experience ranged from two years to more than a decade. 
We chose a total of ten participants, a number that meets McCracken's criteria for a minimum number of interviewees (eight). While it could be argued that ten represents a rather small sample (and this might be one of the shortcomings of this research project), we maintain that, as a qualitative study, this number was sufficient in order to paint a substantial portrait of the situation of CLIL teaching in the region of Cantabria. We make no pretensions of extending our conclusion from a quantitative point of view, but we do believe the ideas and suggestions put forward by all these teachers are representative, and may show a reliable path for university lecturers when it comes to applying the CLIL methodology in a different context.

In order to acquire the maximum amount of useful information for the purposes of this study, we followed the model suggested by Fink (2000), inspired by Kvake (1996): thematizing (determining what is going to be studied), designing (type of interviews and participants), interviewing (according to an interview guide or questionnaire), transcribing (which goes beyond a simple act of copying information, since it provides an opportunity for analysis and reflection), analysing (looking for interconnected codes establishing webs of meanings), verifying, and reporting.

Following these guidelines, we designed a questionnaire with what we believe are the most important issues concerning the teaching and learning processes within the CLIL methodology. This questionnaire also observed McCracken's suggestions in terms of confidentiality and anonymity. Each interview concluded with the signing of a document in which each participant has the right to check the transcripts of their interviews, to modify or eliminate any of the information given, and to be informed about the final results of this research.

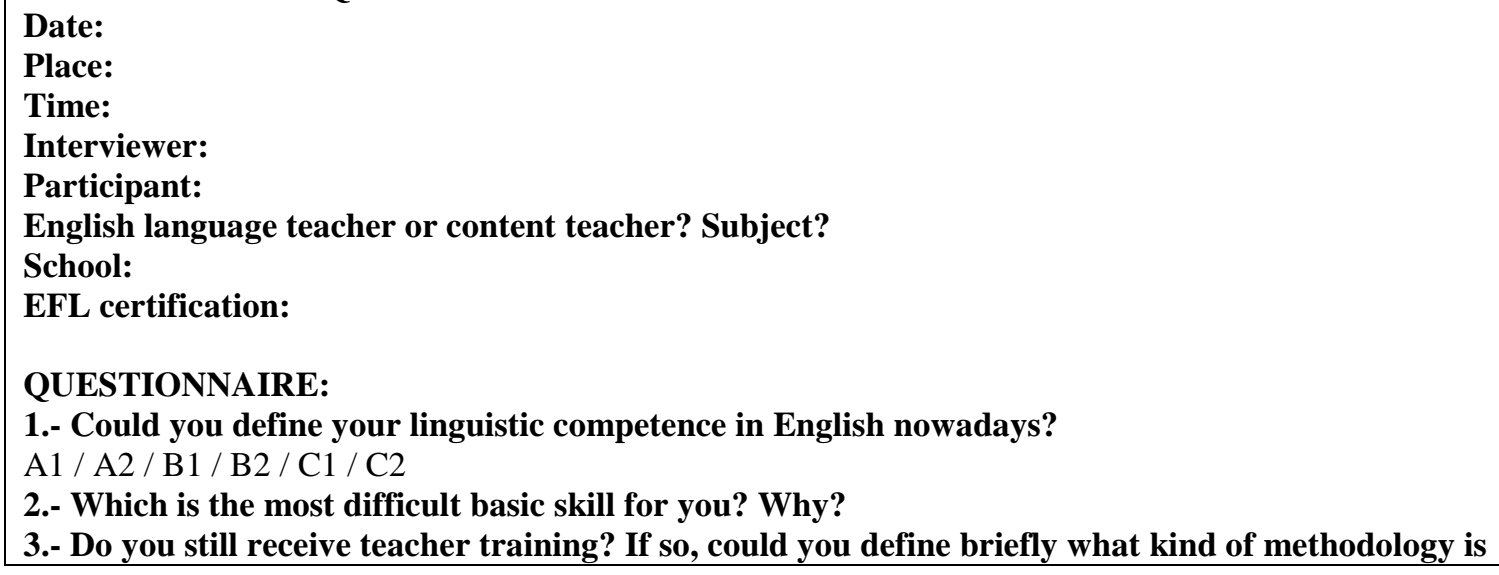


applied to the training activities you participate in?

4.- Could you clearly define CLIL?

5- How would you define your experience as a CLIL teacher?

6.- Generally speaking, do you consider CLIL as a positive approach for your students from the linguistic point of view? And from the content point of view? Why?

7.- Do you think that CLIL necessarily implies a methodological change for both language teachers and content teachers? Why?

8.- What kind of material do you use in your CLIL classes? From publishers? From the internet? Self-produced material?

9.- How would you qualify cooperation between language and content teachers in your school?

10.- Do you think your classes are skill balanced? Yes / No. If not, what percentage would you apply to your participation and what percentage would you apply to that of your students?

11.- Please, rate three aspects which increase difficulty when approaching CLIL teaching.

- Lack of institutional and methodological support.

- Lack of appropriate material in English for different content subjects.

- Lack of time required for the adaptation to a new approach like CLIL.

- Lack of coordination between language and content teachers.

- Lack of linguistic competence in the foreign language on the students' side.

- Lack of linguistic competence in the foreign language on the content teacher's side.

- Lack of knowledge about the content on the language teacher's side.

- Lack of CLIL teacher training.

- Others (could you please specify?).

12.- Do you agree with the following statements? Yes / No / Partially

- CLIL is based on self learning.

- Being a CLIL teacher is a prestigious option in our education system.

- CLIL is clearly beneficial as far as the foreign language is concerned.

- CLIL is as effective as standard classes as far as content learning is concerned.

- CLIL students are more motivated.

13.- In which way is your teaching practice improved or negatively affected by CLIL?

- Identification of students' needs (Improved / Negatively affected / None)

- Student-centred teaching practice (Improved / Negatively affected / None)

- Planning ways of cognitively and linguistically demanding interaction in the classroom (Improved / Negatively affected / None)

- Facilitating the implementation of new ways of assessment (Improved / Negatively affected / None)

- Facilitating new ways of group work, collaborative work, project work, etc. (Improved / Negatively affected / None)

- Facilitating new ways of student production like debate, oral presentations, roleplaying, posters, online material (blog sites, website, wikis, docs, etc.) (Improved / Negatively affected / None)

- Establishing paths of cooperation between content subjects and their teachers (Improved / Negatively affected / None)

14.- Do you consider that adopting the CLIL methodology is inherent to the use of ICT in the classroom? What kinds of ICT resources are more appropriate for this approach in your opinion? 15.- How would you qualify the situation of your school in terms of the adoption of the CLIL methodology?

16.- What kind of methodological advice would you give to university lecturers who would like to implement CLIL at the Universidad de Cantabria?

Figure 4. Questionnaire used on the interviewing process.

With the very last question of the questionnaire, researchers tried to create an inviting atmosphere in order to obtain as much information about our research question as possible. We can also state that although all our questions did guide the content of our participants' stories, we invited them to feel free to skip, add, modify or specify any 
kind of extra information derived from our questions or from their own answers. On quite a few occasions their ideas and opinions went beyond the initial sense of our questions (e.g. some very interesting ideas about the worrying disconnection between educational levels in our country were offered and highly appreciated).

All the interviews were carried out by Javier Barbero in January 2012, both in English and in Spanish, at the Primary and Secondary schools where the participants work. The process of analysing the data took quite a long time as ten interviews had to be carefully listened to and transcribed, each interview lasting approximately half an hour. Following McCracken's guidelines, each transcription was carefully analysed in its own right for internal themes prior to checking for themes that emerged across the transcripts.

\section{RESULTS}

Most of our ten participants' answers are consistent with the literature published on CLIL methodology and implementation. $60 \%$ of teachers say they have a B2 level in English, 20\% a C1 level and 20\% a C2 level. In general, the level of satisfaction seems to be relatively high, but they complain about the workload and prestige of their work as CLIL teachers. All of them accurately define the term CLIL and are generally satisfied with their experience, although they say an extra workload is necessary when working in a bilingual programme. Similarly, in question 12, although CLIL is considered to be beneficial and motivating for students, being a CLIL teacher is not perceived as a prestigious option in our educational system.

The two most difficult aspects concerning CLIL are the lack of institutional and methodological support and the content teacher's lack of linguistic competence in the foreign language. Half of the teachers interviewed qualify the situation of their schools as "good", three of them see it as "okay", and two of them as "not very good". It seems that the higher the consensus around the adoption of CLIL, the better the situation turns out to be. According to our participants, the cooperation at their schools was either really good and productive or it did not work at all. Half of the teachers were quite happy with their schools in this sense but the other half were really disappointed. 
Most of them attend teacher training sessions, and they can see big changes in the kind of classes they receive in comparison to those they received years ago. Now classes seem to be more communicative, with a bigger emphasis on oral skills. Speaking is undoubtedly the most difficult skill for them - up to $80 \%$ say so - and the basic reason they identify is the methodology they experienced when they were students of English, which was mainly based on reading, writing and grammar. This is a big challenge since speaking (together with writing) is the skill they practise most, just like their students.

Answers offer overwhelming agreement in terms of the linguistic benefits of CLIL. Things differ, though, when it comes to analysing the impact on content, as half of the teachers interviewed admit that covering the whole programme in the foreign language is so challenging that they sometimes have to use L1 to do so.

Most of them also agree that CLIL has brought new challenges to their teaching; they see CLIL as an opportunity to change the way things are done in teaching in their schools. All teachers agree that CLIL necessarily implies a methodological change for both language teachers and content teachers, basically because CLIL implies new ways to approach the teaching-learning dynamics. Sticking to traditional methods will simply not work. CLIL enhances interaction in the classroom through group work and collaborative strategies together with new ways of student production. All teachers agree that a student-centred approach within CLIL is more than recommendable as the best way to leave old teaching habits behind. As an immediate consequence, the implementation of new ways of assessment is considered essential. At the end of the day, observing the implementation of CLIL without a single change in assessment methods simply makes no sense. The use of rubrics, visual organisers, feedback tools and review and reflection tools are some of the examples given. In this sense the role of ICT (Information and Communication Technologies) becomes fundamental as a new way to approach the teaching-learning dynamics in detail.

All teachers state that they have to be open-minded to new methodologies and ready to incorporate ICT, visual organizers and new ways of assessment in class. In this respect, most of them agree that classes should be planned according to general objectives, and not to particular content to be learnt. The ICT resources mentioned are specific tools like IWBs, laptops or projectors together with online resources like websites, blog sites, 
wikis, Moodle, forums, virtual classrooms or webquests. Since most teachers - up to $80 \%$ - state that they use self-produced material, the Internet is essential as a source.

All teachers agree that CLIL does not allow you to use traditional methodology: there is simply no way to teach CLIL if you do not use debates, group work and continuous interaction. Classes should be student-centred and not teacher-centred. Cooperation between language departments and content departments is essential. A perfect example is vocabulary: if teachers are not ready to cooperate in the creation of a powerful lexical corpus for every issue related to different content subjects, the CLIL methodology is really difficult to implement. Some teachers say that the use of L1 should not be demonized. In case of communication blockage, L1 is one more resource to be used naturally. However, others say that the use of the English language should be one of the main goals in a CLIL class in order to acquire the demanded content. All teachers recommend university lecturers not to take for granted that the level of English of their students at university will be high. Finally, most teachers agree that the production and reception of oral skills should be one of our biggest interests; paradoxically enough, they also agree that precisely that aspect is one of the weakest points of Spanish students. We have selected some specific comments which we consider particularly relevant:

Participant \#1: CLIL is so dynamic in every subject that you have to teach with a very open mind, much more than in any other kind of methodology. You have to think that something that works brilliantly in one class may be completely useless the following day, that is to say, this is pure dynamism.

A CLIL teacher must be really open to ICT, to new methodological approaches and, moreover, to new ways of assessment. The thing is: how do you assess students who are studying your content through the foreign language? And how do you facilitate that assessment process? Many times you have to put yourself in the place of the student, which is something us teachers are not very used to doing.

Participant \#1: I try to connect with my students through ICT, they love songs, videos or games... what I can say is that all my lesson plans have got at least one game or one video which is linked with some current issue.

Participant \#1: We have to make the mediation through the foreign language nice and attractive to them, and to make them acquire naturally both content and the foreign language.

Participant \#6: They should forget about traditional teaching, I feel sorry for those professors 
who try to preserve that approach!!! Student groups should be smaller, classes should be based on debate-based continuous interaction.

Participant \#7: Professors should not take for granted that their future students will have the level of English they are supposed to have when they have access to University for the first time.

We have to make sure they speak; no matter if they are not accurate or fluent... that is to say, we have to make sure they forget that embarrassing feeling Spaniards traditionally have when it comes to speaking foreign languages. I belong to a generation of people who do have that feeling... so we have to make sure we get rid of it. After all, the only important thing is to communicate; it doesn't really matter if even I myself am not that accurate, because at the end of the day I am not an English teacher. Even if they don't express themselves correctly, I want to be sure they can communicate content accurately enough... no matter if their English is not perfect. They make an effort, they create sentences, they manage content, they structure it all... and I think that's fine and I do appreciate that.

Participant \#8: Visual aids are really important, if pupils have that kind of material they understand everything much better and in that sense ICT are essential.

Participant \#9: They should look for more practical ways to show content to students. Traditional teaching simply does not work and ICT should have a very relevant role together with collaborative work.

Following this research came a period of experimentation and dissemination that we have described in detail elsewhere (Barbero and González in press). We tried to apply a CLIL-oriented methodology in our own university classes (English in History and Civil Engineering degrees) and shared our experience with teachers involved in the process of teaching subjects in English (at our University's Teacher Training Centre). The feedback received in both cases (through the University's standard evaluation process and through informal, unrecorded interviews with our students and colleagues) has reinforced our perception: the methodological principles applied in primary and secondary classes can be successfully extended to the tertiary level, although more research needs to be conducted, increasing the number of participants at pre-university levels and extending the "long interviews" to university level.

In order to facilitate the visibility and dissemination of our research, we have attempted to summarize its final results in the following “CLIL-methodology Decalogue”: 
1. Communication is a must. English should be used as much as possible, but the mother tongue can also be used in case of communication blockage.

2. Scaffolding is essential. Identify language demands and provide support strategies. Use visual aids and written language whenever necessary. All students, but particularly all those whose listening skills are not the best, will appreciate the use of slides summarizing the main ideas stated in class. Model and break up the tasks if appropriate.

3. A reference lexical corpus is required for every task. Advance work (with warm-up activities like video comprehension, webquests or the like) on specific vocabulary should be done prior to the explanation of cognitively challenging content.

4. Use ICT, in particular software and on-line material in English.

5. Use a student-centred approach. Put yourself in the students' position. Provide the opportunity for as much hands-on learning as possible. Use pair work and group work.

6. In assessment, content should be a priority over language: linguistic competence in the foreign language is an added value which should be rewarded, but the lack of fluency in the foreign language should not be a major obstacle for a positive evaluation.

7. Use diverse assessment instruments: self-assessment, peer assessment, rubrics, and language and content portfolios.

8. Repeat and consolidate. Do not hesitate to repeat, paraphrase, and/or present information in different formats.

9. Plan carefully in order to be flexible.

10. Turn problems into opportunities. Be bold as far as methodology is concerned and take advantage of this new educational context to work on a different paradigm. Teachers are facilitators and mediators between language and content, not mere transmitters of knowledge. Assess your teaching practice (with instruments like the EPOSTL, or “The CLIL Teachers' Competences Grid”). 


\section{CONCLUSIONS}

The research carried out with a group of CLIL teachers at Primary and Secondary levels is consistent with the literature about CLIL experimentation and methodology. They both show that:

- CLIL is much more than a new way to have access to content and English; it is a new educational path we can take advantage of in order to implement new ways to approach classes at university.

- CLIL is here to stay: experiences in Primary and Secondary Education can help Tertiary Education to redefine a new scenario where new resources and approaches may be put forward.

- Teaching methodology needs to change in order to be successful. Some basic concepts and strategies, which we have included in our "decalogue”, need to be considered: a student-centred approach, scaffolding, priority of content over language (in assessment), lexical corpora, ICT, self-assessment, repetition, planning and flexibility.

- According to our own experience, qualitative research has proven to be a powerful tool to obtain valuable information. In this sense, we observe that there is no real distance between the theoretical basis of CLIL and the methodological practice of our teachers.

\section{REFERENCES}

Alegría de la Colina, A. and García Mayo, M.P. 2009. “Oral interaction in task-based EFL learning: The use of the L1 as a cognitive tool”. IRAL: International Review of Applied Linguistics 47 (3), 325-345.

Anderson, L.W. and Krathwohl, D.R. 2001. A Taxonomy for Learning, Teaching, and Assessing: A Revision of Bloom's Taxonomy of Educational Objects. New York: Longman. 
Antón, M. and DiCamilla, F. 1998. "Socio-cognitive functions of L1 collaborative interaction in the L2 classroom”. Canadian Modern Language Review 54, 314342.

Barbero, J. and González, J.A. in press. "CLIL at university: Transversal integration of English language and content in the curriculum at the University of Cantabria”. In Breeze, R., C. Martínez-Pasamar, C. Llamas-Saiz and C. Tabernero-Sala (Eds.) Integration of Theory and Practice in CLIL. Amsterdam: Rodopi.

Bloom, B.S. 1956. Taxonomy of Educational Objectives. Handbook I: The Cognitive Domain. New York: David McKay.

Casal, S. 2007. "The integrated curriculum, CLIL and constructivism”. Revista Española de Lingüística Aplicada, volumen monográfico, 55-65.

CEFTRAIN Project. 12 April 2013 <http://www.helsinki.fi/project/ceftrain>

Churchill, G.A. Jr. 1991. Marketing Research. Methodological Foundations. Chicago: Dryden Press.

Costa, F. and Coleman, J.A. 2010. "Integrating content and language in higher education in Italy: Ongoing research”. International CLIL Research Journal 1 (3), 19-29.

Cummins, J. 1984. "Wanted: A theoretical framework for relating language proficiency to academic achievement among bilingual students, language proficiency and academic achievement”. In Rivera, C. (Ed.) Language Proficiency and Academic Achievement. Clevedon, Avon: Multilingual Matters, 2-20.

Dalton-Puffer, C. and Smit, U. (Eds.) 2007. Empirical Perspectives on CLIL Classroom Discourse. Frankfurt am Main: Peter Lang.

De Graaff, R., Koopman G.J. and Westhoff, G. 2007. "Identifying effective L2 pedagogy in content and language integrated learning”. Viewz (Vienna English Working Papers) 16 (3), 12-19.

DiCicco-Bloom, B. and Crabtree, B.F. 2006. "The qualitative research interview”. Medical Education 40, 314-321. 
Dillman, D.A. 1978. Mail and Telephone Surfers. The Total Design Method. New York: Wiley Interscience.

Domínguez, A. El currículum integrado. 18 June 2013 < $\underline{\text { www.uhu.es/ }}$ antonia.dominguez/docs/cintegrado.pps>

Spoken Performances Illustrating the 6 Levels of the Common European Framework of Reference for Languages. 12 April 2013 < http://www.ciep.fr/en/publi_ evalcert/dvd-productions-orales-cecrl>

Europass. 12 April 2013 <http://europass.cedefop.europa.eu/en/documents/europeanskills-passport/language-passport/templates-instructions>

Eldridge, J., Neufeld, S. and Hancioğlu, N. 2010. "Towards a lexical framework for CLIL”. International CLIL Research Journal 1 (3), 80-95.

Fernández, D.J. 2009. “CLIL at the university level: Relating language teaching with and through content teaching”. Latin American Journal of Content \& Language Integrated Learning 2 (2), 10-26.

Fink, A.S. 2000. "The role of the researcher in the qualitative research process. A potential barrier to archiving qualitative data”. Forum Qualitative Sozialforschung / Forum: Qualitative Social Research 1(3), Art. 4. 15 June 2013 <http://nbnresolving.de/urn:nbn:de:0114-fqs000344>

Gozalo, A. 2011. Del Currículo de Lenguas Extranjeras a la Práctica Docente: Algunas Reflexiones Previas (paper presented at CEP Torrelavega, unpublished).

Halbach, A. 2012. “Adapting content subject for bilingual Tteaching”. Encuentro 21, 34-41.

Kvale, S. 1996. InterViews. An Introduction to Qualitative Research Interviewing. Thousand Oaks: Sage.

Lasagabaster, D. and Sierra, J.M. 2009. “Language attitudes in CLIL and traditional EFL classes”. International CLIL Research Journal 1 (2), 4-17.

Liubinienè, V. 2009, “Developing listening skills”. CLIL Kalbu Studijos 15, 89-93.

McCracken, G. 1988. The Long Interview. Thousand Oaks: Sage. 
Marsh D. and Frigols M.J. 2007. "CLIL as a catalyst for change in language education”. Babylonia: A Journal of Language Teaching and Learning 3 (15), 3337.

Miller, D.C. 1991. Handbook of Research Design and Social Measurement. Newbury Park: Sage.

Muñoz, C. 2007. "CLIL: Some thoughts on its psycholinguistic principles”. Revista Española de Lingüística Aplicada, volumen monográfico, 17-26.

Novotná, J., Hadj-Moussová, Z. and Hofmannova, M. 2001 “Teacher training for CLIL - Competences of a CLIL teacher”. Proceedings SEMT 1, 122-126.

Storch, N. and Aldosari. A. 2010. "Learners' use of first language (Arabic) in pair work in an EFL class”. Language Teaching Research 14 (4), 355-375.

Storch, N. and Wigglesworth, G. 2003. "Is there a role for the use of the L1 in an L2 setting?” TESOL Quarterly 32 (4), 760-770.

Surveylang 2012, First European Survey on Language Competences. 12 April 2013 $<\underline{\text { http://ec.europa.eu/languages/eslc }>}$

Universidad de Cantabria, Plan de Capacitación Lingüística. 12 April 2013 <http://www.unican.es/NR/rdonlyres/DA3BFE08-FA65-463F-951C1A5E0BBBDC5D/ 83594/NormativaGrado17122012.pdf>

Van de Pol, J., Volman M. and Beishuizen, J. 2010. "Scaffolding in teacher-student interaction: A decade of research”. Educ Psychol 22, 271-296.

Vártuki, A. 2010. "Linguistic benefits of the CLIL approach: Measuring linguistic competences”. International CLIL Research Journal 1 (3), 67-79.

Vázquez, G. 2007. "Models of CLIL: An evaluation of its status drawing on the German experience: A critical report on the limits of reality and perspectives”. Revista Española de Lingüística Aplicada, volume monográfico, 95-111.

Wilkinson, R. (Ed.) 2004. Integrating Content and Language. Meeting the Challenge of Multilingual Higher Education. Maastricht: Universitaire Pers Maastricht.

Wilkinson, R. and Zegers, V. (Eds.) 2007. Researching Content and Language Integration in Higher Education. Maastricht: Universitaire Pers Maastricht. 
Wilkinson, R. and Zegers, V. (Eds.) 2008. Realizing Content and Language Integration in Higher Education. Maastricht, Netherlands: Maastricht University.

Woodside A.G. and Wilson E.J. 1995. “Applying the long interview”. Direct Marketing Research. Journal of Direct Marketing 9 (I), 37-55.

Received: 28 June 2013

Accepted: 27 August 2013

Cite this article as:

González, J.A. \& Barbero, J. 2013. "Building bridges between different levels of education: Methodological proposals for CLIL at university”. Language Value 5 (1), 1-23. Jaume I University ePress: Castelló, Spain. http://www.e-revistes.uji.es/languagevalue. DOI: http://dx.doi.org/10.6035/LanguageV.2013.5.2

ISSN 1989-7103

Articles are copyrighted by their respective authors 